\title{
Agronomic performance of grain sorghum in different spatial arrangements
}

\section{Desempenho agronômico do sorgo granífero em diferentes arranjos espaciais}

\author{
Antonio Germano Carpim Rocha ${ }^{1}$; Eduardo Lima do Carmo ${ }^{2}$; \\ Guilherme Braga Pereira Braz ${ }^{2 *}$; Luiz Fernando Ribeiro Júnior ${ }^{1}$; Carlos César \\ Evangelista de Menezes ${ }^{2}$; Gustavo André Simon²; João Vitor Alves de Sousa ${ }^{1}$; \\ Maria Eduarda Carpim Rocha ${ }^{3}$
}

\section{Highlights:}

Reducing spacing has less influence on sorghum than increasing population density. Taller plants with a smaller stem diameter are obtained in larger populations. In higher populations, there is a reduction in the values of the yield components. The increase in population provides increases in grain yield per area.

\begin{abstract}
Grain sorghum has been cultivated extensively in the Central-West region of Brazil in succession with soybean, since the species tolerates the low rainfall conditions recorded during this growing season. Phytotechnological adjustments for sorghum are still necessary in order to exploit the maximum yield potential of the crop. In this context, altering the plant distribution may result in better utilization of the growing area with a consequent increase in grain yield. On this basis, field experiments were conducted with two grain sorghum hybrids, replicated in two different locations, in order to evaluate the effect of the spatial arrangement of plants on the agronomic performance of grain sorghum. The design was a randomized complete block design in a $2 \times 4$ factorial scheme, with five replications. The factors consisted of two row spacings $(0.50$ and $0.25 \mathrm{~m})$ and four plant densities: $120,180,240$, and 300 thousand plants ha ${ }^{-1}$. The sorghum hybrids used were $1 \mathrm{G} 244^{\circledR}$ and $1 \mathrm{G} 100^{\circledR}$. At harvest, morphological characteristics, yield components, and grain yields were evaluated. Row spacing did not influence the characteristics evaluated except for the plant height of for both hybrids, in addition to the stem diameter, tillering, and mass of a thousand grains for $1 \mathrm{G} 100^{\circledR}$. The increase in plant density provided an increase in grain yield, being the highest number of panicles per area the most expressive component for this behavior.
\end{abstract}

Key words: Second season crops. Narrow spacing. Sorghum bicolor.

1 Discentes do Curso de Mestrado, Programa de Pós-Graduação em Produção Vegetal, Universidade de Rio Verde, UniRV, Rio Verde, GO, Brasil. E-mail: antoniocarpim@hotmail.com; luizferunai@hotmail.com; alvessousa481@gmail.com

2 Profs. Drs., Programa de Pós-Graduação em Produção Vegetal, UniRV, Rio Verde, GO, Brasil. E-mail: eduardo@unirv.edu.br; guilhermebrag@gmail.com; carloscesar@unirv.edu.br; simon@unirv.edu.br

3 Discente do Curso de Graduação em Agronomia, UniRV, Rio Verde, GO, Brasil. E-mail: eduardacarpim@gmail.com

* Author for correspondence 


\section{Resumo}

O sorgo granífero tem sido amplamente cultivado na região Centro-Oeste do Brasil em sucessão com a soja, uma vez que a espécie apresenta tolerância as condições de baixa pluviosidade registradas neste período de cultivo. Ajustes fitotécnicos para o sorgo ainda são necessários visando explorar o potencial produtivo máximo que a cultura apresenta. Neste contexto, alterações na distribuição de plantas pode resultar em melhor aproveitamento da área de cultivo com decorrente aumento da produtividade de grãos. Embasado nisso, foram conduzidos experimentos a campo com dois híbridos de sorgo granífero, replicados em duas localidades distintas, com objetivo de avaliar o efeito do arranjo espacial de plantas no desempenho agronômico do sorgo granífero. O delineamento utilizado foi o de blocos completos ao acaso em esquema fatorial $2 \times 4$, com cinco repetições. Os fatores consistiram em dois espaçamentos entrelinhas de semeadura $(0,50$ e $0,25 \mathrm{~m})$ e quatro populações de plantas: $120 ; 180 ; 240$ e 300 mil plantas $\mathrm{ha}^{-1}$. Os híbridos de sorgo utilizados foram $1 \mathrm{G} 244^{\circledR}$ e $1 \mathrm{G} 100^{\circledR}$. Na colheita, avaliou-se características morfológicas, componentes do rendimento e produtividade de grãos. O espaçamento entrelinhas de semeadura não influenciou nas características avaliadas a exceção da altura de plantas, para ambos os híbridos, além do diâmetro de colmo, perfilhamento e massa de 1000 grãos para o $1 \mathrm{G} 100^{\circledR}$. O acréscimo da população de plantas proporcionou incremento da produtividade de grãos, visto que o maior número de panículas por área foi o componente mais expressivo.

Palavras-chave: Culturas de safrinha. Espaçamento reduzido. Sorghum bicolor.

\section{Introduction}

The need to increase cereal yield in the face of growing demand for food has favored the cultivation of sorghum, as it is an alternative energy source of animal feed and human food. Some cultural practices, such as the use of different spatial arrangements of plants, can contribute to increasing grain yield (Albuquerque, Von Pinho, Brant, \& Mendes, 2011). The spatial arrangement of plants consists of the various combinations of spacing between lines and planting densities (plant population) that allow the best distribution of plants in the cultivation area. In this context, optimizing plant distribution can help to increase sorghum yield (Hammer \& Broad, 2003).

One way to increase the amount of radiation intercepted by the crop is to increase the plant population in the cultivation area. However, the use of high population densities can result in increased intraspecific competition for water, light, and nutrients, which can negatively affect the yield potential of the crop (Cox, Cherney, \& Shields, 2010; Walker et al., 2010). On the other hand, the technique of reducing the spacing between rows while maintaining the same plant population reduces competition, providing an equidistant arrangement of these in the cultivation area. This contributes to better interception of solar radiation, less water loss through evaporation, and better distribution of the root system (May, Campanha, Silva, Freitas, \& Albuquerque, 2014).

Over the years, the densification of crops has been adopted by sorghum producers in several countries, with the main objective of increasing yield and reducing production costs. As an example of such research, in the United States, Stichler, McFarland and Coffman (1997) found increases in grain yield with reduced spacing between rows from $0.90 \mathrm{~m}$ to $0.70 \mathrm{~m}$, with sorghum grown in populations greater than 140 thousand plants $\mathrm{ha}^{-1}$. Baumhardt and Howell (2006) did not find an effect of plant density on the grain yield of sorghum sown among populations of 120 to 160 thousand plants ha${ }^{1}$. However, regarding the effect of spacing between rows, a $7 \%$ increase in grain yield of this crop was observed for sorghum sown by $0.38 \mathrm{~m}$ compared with $0.76 \mathrm{~m}$.

Still, Al-Bedairy, Alsaadawi and Shati (2013) working with plant populations of 66,133 , and 266 thousand plants $\mathrm{ha}^{-1}$, observed a reduction in the 
number of emerged weeds of $26 \%, 31 \%$, and $42 \%$, respectively, in addition to a greater sorghum grain yield for the highest sowing density. In Brazil, in studies carried out by Albuquerque et al. (2011), the reduction in spacing between rows from $0.90 \mathrm{~m}$ to $0.50 \mathrm{~m}$ promoted an increase in grain yield, but there was no influence of populations $(100,140$, and 180 thousand plants $\mathrm{ha}^{-1}$ ), regardless of the cultivar of sorghum used.

Evaluation of the productive behavior of graniferous sorghum hybrids in different plant arrangements is necessary, since the new genotypes available on the market have a smaller size, high precocity, and higher yield (Avelino et al., 2011). These characteristics suggest the possibility of cultivating sorghum in denser plant arrangements. The execution of this work sought to evaluate the effect of spatial arrangements of plants on the agronomic performance of two hybrids of grain sorghum.

\section{Material and Methods}

The experiments were conducted in the Midwest region of Brazil, in the State of Goiás, municipality of Rio Verde, between the months of February and July 2017, in a second crop cultivation system. Two experiments were installed using two sorghum hybrids separately, which were grown in two locations whose geographical coordinates are $17^{\circ} 45^{\prime} 59.20^{\prime \prime} \mathrm{S} ; 1^{\circ} 2^{\prime} 15.01^{\prime \prime} \mathrm{W}$ (Site 1) and $17^{\circ} 47$ '5” S; 50 57' 53" W (Site 2), with altitudes of $837 \mathrm{~m}$ and $756 \mathrm{~m}$, respectively.

According to the Köppen classification, the climate in the locations where the experiments were conducted is of the Aw type, which is identified as tropical with a dry season, characterized by having more intense rains in summer than in winter, presenting a defined dry season. Data on rainfall and average air temperature during the execution of the experiments are shown in Figure 1.

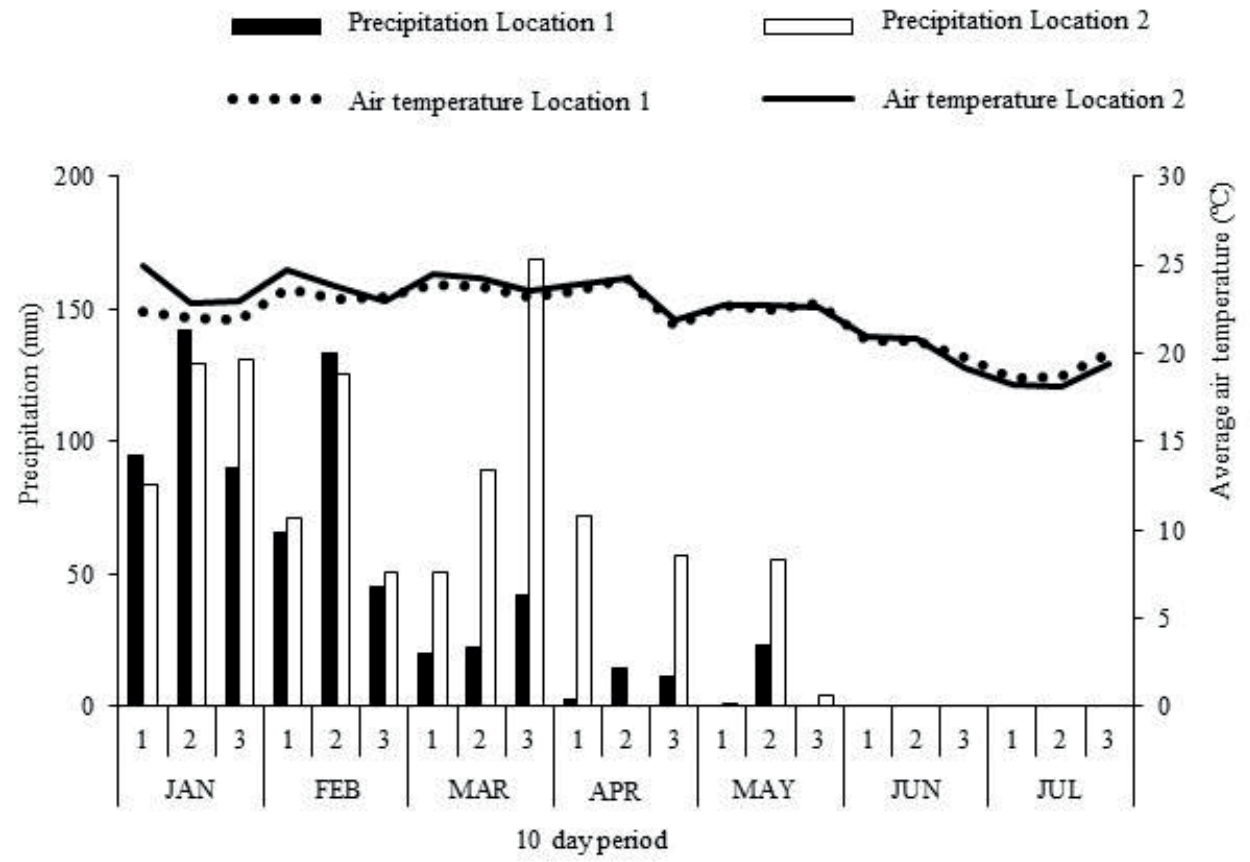

Figure 1. Rainfall and average air temperature in the experimental areas during sorghum experiments. Rio Verde (GO), 2017. 
Both areas were under a no-tillage system under soy straw and soil classified as Red Oxisol Latossol (Empresa Brasileira de Pesquisa Agropecuária [EMBRAPA], 2013). Soil samplings were carried out prior to implementation of the experiments, at a depth of $0-0.2 \mathrm{~m}$. The analytical results showed the following physical-chemical attributes: $\mathrm{pH}$ in $\mathrm{CaCl}_{2}$ of $5.7,14 \mathrm{~g} \mathrm{~kg}^{-1} \mathrm{MO}, 280 \mathrm{~g} \mathrm{~kg}^{-1}$ of clay, $70 \mathrm{~g} \mathrm{~kg}^{-1}$ of silt, and $650 \mathrm{~g} \mathrm{~kg}^{-1}$ of sand (clay loam texture) for site 1 and $\mathrm{pH}$ in $\mathrm{CaCl}_{2}$ of $4.6,16.4 \mathrm{~g} \mathrm{~kg}^{-1} \mathrm{MO}, 600 \mathrm{~g}$ $\mathrm{kg}^{-1}$ of clay, $230 \mathrm{~g} \mathrm{~kg}^{-1}$ of silt, and $170 \mathrm{~g} \mathrm{~kg}^{-1}$ of sand (clay texture) for site 2 .

Before the installation of the experiment, the weeds in the areas were desiccated by using the herbicide glyphosate (1440 g a.e. ha-1) combined with 2,4-D amine (536 g a.e. ha $\mathrm{g}^{-1}$ ). The sorghum hybrids used were the grain sorghum, Dow $1 \mathrm{G} 244^{\circledR}$ and Dow $1 \mathrm{G} 100^{\circledR}$, which present high yield and stability under second harvest cultivation conditions and precocity (Dow AgroSciences, 2018). The choice of these materials is related to the morphological characteristics of the hybrids, which, due to their small size and resistant stalk, tend to have less sensitivity to lodging when there is variation in the plant population.

The experimental design used was a randomized block, with five replications, in a $2 \times 4$ factorial scheme. The first factor consisted of two spacings between sowing lines (traditional and dense: 0.50 $\mathrm{m}$ and $0.25 \mathrm{~m}$, respectively). The second consisted of four plant populations: 120, 180, 240, and 300 thousand plants ha-1, with 180 thousand plants ha1 , as recommended by the company that owns the hybrids. The plots were $5 \mathrm{~m}$ long by $2 \mathrm{~m}$ wide, for a total area of $10 \mathrm{~m}^{2}$. The useful area was derived from the disposal of $0.50 \mathrm{~m}$ from each end (border) of the plot, using 2 and 4 central sowing lines, for the spacing of $0.50 \mathrm{~m}$ and $0.25 \mathrm{~m}$, respectively, totaling $4 \mathrm{~m}^{2}$.

The experiments were sown in February 2017, on the 20th and 26th, for sites 1 and 2, respectively. Seed distribution was carried out by a continuous flow seeder, mounted on a hydraulic system, composed of 7 double eccentric discs, regulated to distribute 400 thousand seeds ha ${ }^{-1}$ at both spacings. At the time, $150 \mathrm{~kg} \mathrm{ha}^{-1}$ of $\mathrm{P}_{2} \mathrm{O}_{5}$ was distributed in a furrow. Ten days after emergence, manual thinning was performed to adjust the desired plant populations in each treatment. In addition, cover fertilization was carried out, in which $80 \mathrm{~kg} \mathrm{ha}^{-1}$ of $\mathrm{N}$ and $40 \mathrm{~kg}$ $\mathrm{ha}^{-1}$ of $\mathrm{K}_{2} \mathrm{O}$ were applied manually (by haul), using urea and potassium chloride, respectively.

Twenty days after the emergence of the plants, the herbicide atrazine was applied at a dose of $2000 \mathrm{~g}$ a.i. $\mathrm{ha}^{-1}$, for the control of dicotyledonous weeds. Throughout the crop development cycle, manual weeding was carried out as a complement in the control of monocotyledonous weeds. Pest management was performed according to the technical needs of the crop, without allowing damage to the development of sorghum to be caused by the presence of these weeds. After the flowering of the sorghum (reproductive stage), the panicles of the plants present in the useful area of the plots were covered using Kraft paper bags to protect against bird attacks.

The experiments were harvested on July 7 and 9, 2017 (sites 1 and 2, respectively), using a tool called a cleaver. On these occasions, plant height was evaluated in the useful area of the plots, in 10 continuous plants, using a measuring tape, measuring from the ground to the top of the panicle. Stem diameter was evaluated using a caliper positioned between the first and second stalk knots in relation to the soil. The number of tillers, panicle length, and panicle mass were also recorded. In addition, the percentage of lodging of sorghum was evaluated using a scale in which $0 \%$ represented the absence of lodging and 100\% represented all lodged plants. After all sorghum panicles were harvested from the useful area of the plots, they were subjected to the process of trailing and separating the grains by introducing them into a cereal whisk and, subsequently, the mass of a thousand grains was obtained and yield calculated using a moisture correction of $13 \%$. 
After the data were obtained, individual variance analysis was performed for each location. Then, homogeneity tests for residual variances were performed. Subsequently, after the homogeneity of variances was verified, a joint variance analysis was carried out involving the two experimental sites for each sorghum hybrid. When a significant difference was found between spacings by analysis of variance, they were analyzed separately by regression analysis. Statistical analyses were performed using the Sisvar computer program (Ferreira, 2011).

\section{Results and Discussion}

Sowing at different spacings interfered with plant height of the cultivated materials and some components of the hybrid $1 \mathrm{G} 100{ }^{\circledR}$ yield. There was an effect of the population density for all characteristics and hybrids evaluated (Table 1).

Table 1

Summary of analysis of variance for the variables plant height (AP), stem diameter (DC), tillering (PF), panicle length (CP), panicle mass (MP), thousand grain mass (MMG), and grains yield (GY). Rio Verde (GO), 2017

\begin{tabular}{|c|c|c|c|c|c|c|c|c|}
\hline \multirow{3}{*}{ FV } & \multirow{3}{*}{ GL } & \multicolumn{7}{|c|}{$\mathrm{QM}$} \\
\hline & & \multicolumn{7}{|c|}{$1 \mathrm{G} 244^{\circledR}$} \\
\hline & & AP & $\mathrm{DC}$ & $\mathrm{PF}$ & $\mathrm{CP}$ & MP & MMG & GY \\
\hline ENS & 1 & $0.3713^{* *}$ & $1.764^{* *}$ & $0.613^{\mathrm{ns}}$ & $2.92^{\mathrm{ns}}$ & $849.56^{*}$ & $2.35^{\text {ns }}$ & $48871369^{* *}$ \\
\hline ESP & 1 & $0.0202^{* *}$ & $0.030^{\mathrm{ns}}$ & $0.013^{\mathrm{ns}}$ & $1.68^{\mathrm{ns}}$ & $0.26^{\mathrm{ns}}$ & $1.29^{\mathrm{ns}}$ & $7527^{\mathrm{ns}}$ \\
\hline POP & 3 & $0.0166^{* *}$ & $0.751^{* *}$ & $2.479^{* *}$ & $35.92^{* *}$ & $2837.22^{* *}$ & $14.42^{* *}$ & $13466103^{* *}$ \\
\hline ENS*ESP & 1 & $0.0118^{* *}$ & $0.046^{\mathrm{ns}}$ & $0.113^{\text {ns }}$ & $7.36^{\mathrm{ns}}$ & $368.34^{\mathrm{ns}}$ & $5.69^{\mathrm{ns}}$ & $514417^{\mathrm{ns}}$ \\
\hline ENS*POP & 3 & $0.0015^{\mathrm{ns}}$ & $0.040^{\mathrm{ns}}$ & $0.479^{\text {ns }}$ & $0.64^{\mathrm{ns}}$ & $25.51^{\mathrm{ns}}$ & $2.13^{\mathrm{ns}}$ & $183625^{\mathrm{ns}}$ \\
\hline ESP*POP & 3 & $0.0005^{\mathrm{ns}}$ & $0.023^{\mathrm{ns}}$ & $0.013^{\mathrm{ns}}$ & $0.83^{\mathrm{ns}}$ & $46.51^{\mathrm{ns}}$ & $1.38^{\mathrm{ns}}$ & $174940^{\mathrm{ns}}$ \\
\hline ENS*ESP*POP & 3 & $0.0005^{\mathrm{ns}}$ & $0.009^{\mathrm{ns}}$ & $0.646^{\mathrm{ns}}$ & $0.18^{\mathrm{ns}}$ & $70.58^{\mathrm{ns}}$ & $1.01^{\mathrm{ns}}$ & $288207^{\mathrm{ns}}$ \\
\hline Resíduo & 56 & 0.0006 & 0.029 & 0.440 & 2.37 & 212.42 & 2.06 & 549467 \\
\hline \multirow[t]{2}{*}{ CV (\%) } & - & 2.05 & 10.47 & 136.09 & 5.45 & 23.71 & 7.33 & 11.60 \\
\hline & & \multicolumn{7}{|c|}{$1 \mathrm{G} 100^{\circledR}$} \\
\hline ENS & 1 & $0.0945^{* *}$ & $0.71^{* *}$ & $0.05^{\mathrm{ns}}$ & $0.71^{* *}$ & $3276.80^{* *}$ & $49.03^{* *}$ & $1376922^{* *}$ \\
\hline ESP & 1 & $0.0177^{* *}$ & $0.09^{*}$ & $4.05^{*}$ & $0.08^{\mathrm{ns}}$ & $154.57^{\mathrm{ns}}$ & $47.32^{* *}$ & $12863703^{\mathrm{ns}}$ \\
\hline POP & 3 & $0.0234^{* *}$ & $0.50^{* *}$ & $2.43^{*}$ & $0.50^{* *}$ & $1469.69^{* *}$ & $6.85^{* *}$ & $1113^{* *}$ \\
\hline ENS*ESP & 1 & $0.0056^{\mathrm{ns}}$ & $0.03^{\mathrm{ns}}$ & $0.20^{\mathrm{ns}}$ & $0.03^{\mathrm{ns}}$ & $66.10^{\text {ns }}$ & $11.87^{* *}$ & $1113^{\mathrm{ns}}$ \\
\hline ENS*POP & 3 & $0.0007^{\mathrm{ns}}$ & $0.02^{\mathrm{ns}}$ & $0.35^{\mathrm{ns}}$ & $0.02^{\mathrm{ns}}$ & $78.14^{\mathrm{ns}}$ & $1.86^{\mathrm{ns}}$ & $446549^{\mathrm{ns}}$ \\
\hline ESP*POP & 3 & $0.0003^{\mathrm{ns}}$ & $0.06^{*}$ & $0.08^{\mathrm{ns}}$ & $0.05^{\mathrm{ns}}$ & $100.15^{\mathrm{ns}}$ & $0.65^{\mathrm{ns}}$ & $333652^{\mathrm{ns}}$ \\
\hline ENS*ESP*POP & 3 & $0.0001^{\mathrm{ns}}$ & $0.05^{*}$ & $0.03^{\mathrm{ns}}$ & $0.05^{\mathrm{ns}}$ & $33.97^{\mathrm{ns}}$ & $0.06^{\mathrm{ns}}$ & $1259757^{\mathrm{ns}}$ \\
\hline Resíduo & 56 & 0.0017 & 0.02 & 0.85 & 0.02 & 86.84 & 1.60 & $526391^{\mathrm{ns}}$ \\
\hline CV (\%) & - & 3.32 & 7.69 & 123.19 & 7.69 & 16.91 & 5.45 & 10.84 \\
\hline
\end{tabular}

$* *$ * significant at $1 \%$ and $5 \%$ probability, respectively by the $\mathrm{F}$ test.

Plants with the widest spacing between rows $(0.50 \mathrm{~m})$ were $3 \mathrm{~cm}$ higher than those with narrower spacing $(0.25 \mathrm{~m})$ for both cultivated materials. As for the populations, there was an increasing linear behavior as the number of plants increased, in which the difference between population extremes was between 7 and $8 \mathrm{~cm}$, considering the respective hybrids evaluated (Figure 2a). 
Plant height is influenced by competition for light. Therefore, those grown in sowing lines spaced $0.25 \mathrm{~m}$ apart are conditioned in an environment with a more equidistant distribution in the growing area, minimizing competition for light in the same row. These results are similar to those obtained by Albuquerque et al. (2011), who evaluated interline spacing of $0.50,0.70$, and $0.90 \mathrm{~m}$ and found significant increases in plant height in the upper spacing in grain sorghum cultivation. Snider, Rapera and Schwabb (2012) evaluated sweet sorghum cultivars in different arrangements and locations in the United States and observed that spacing did not affect plant height, which demonstrates the opposite behavior of grain sorghum cultivars. This difference in behavior is possibly explained by the phenotypic and genotypic characteristics of the cultivated materials.
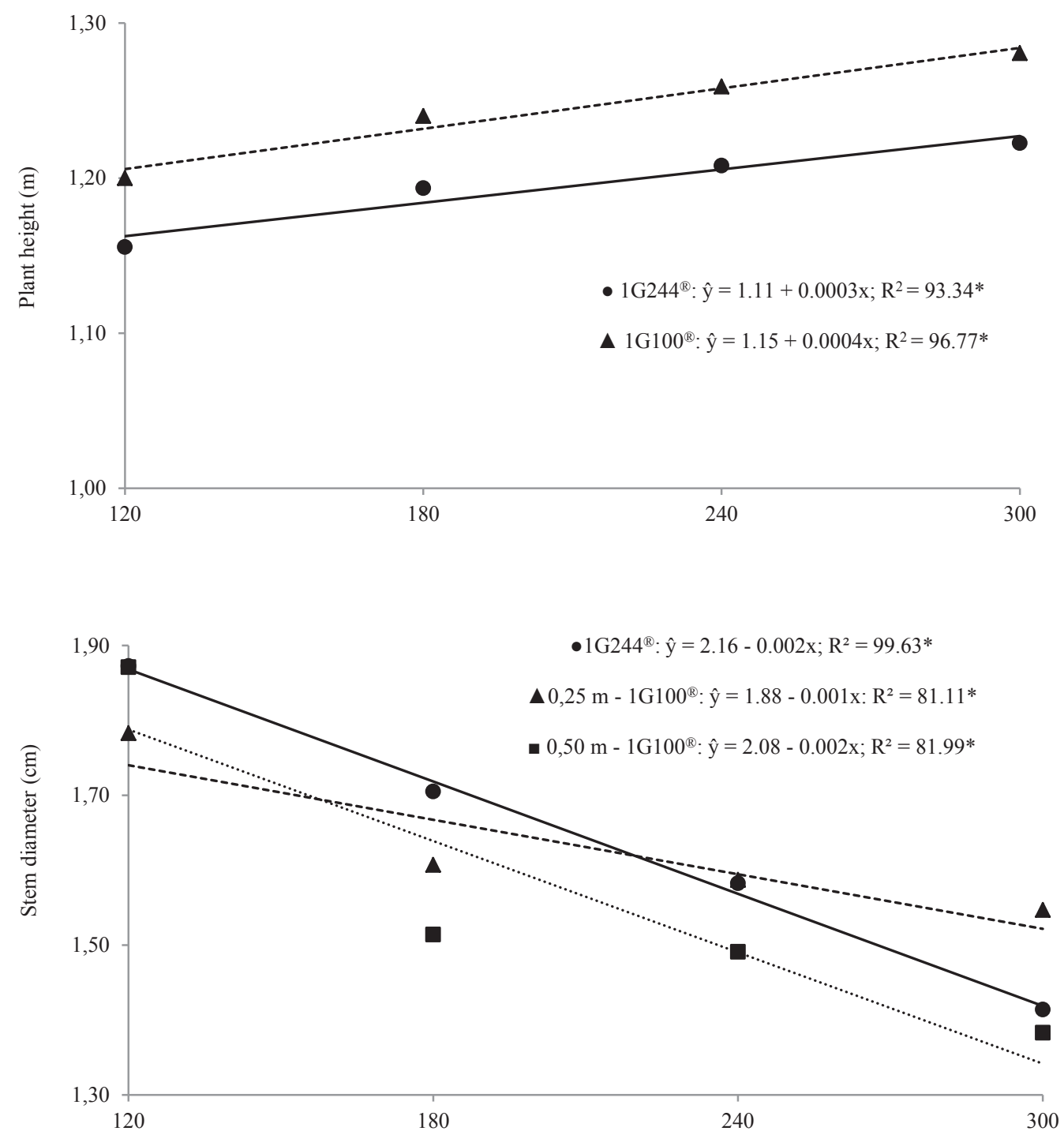


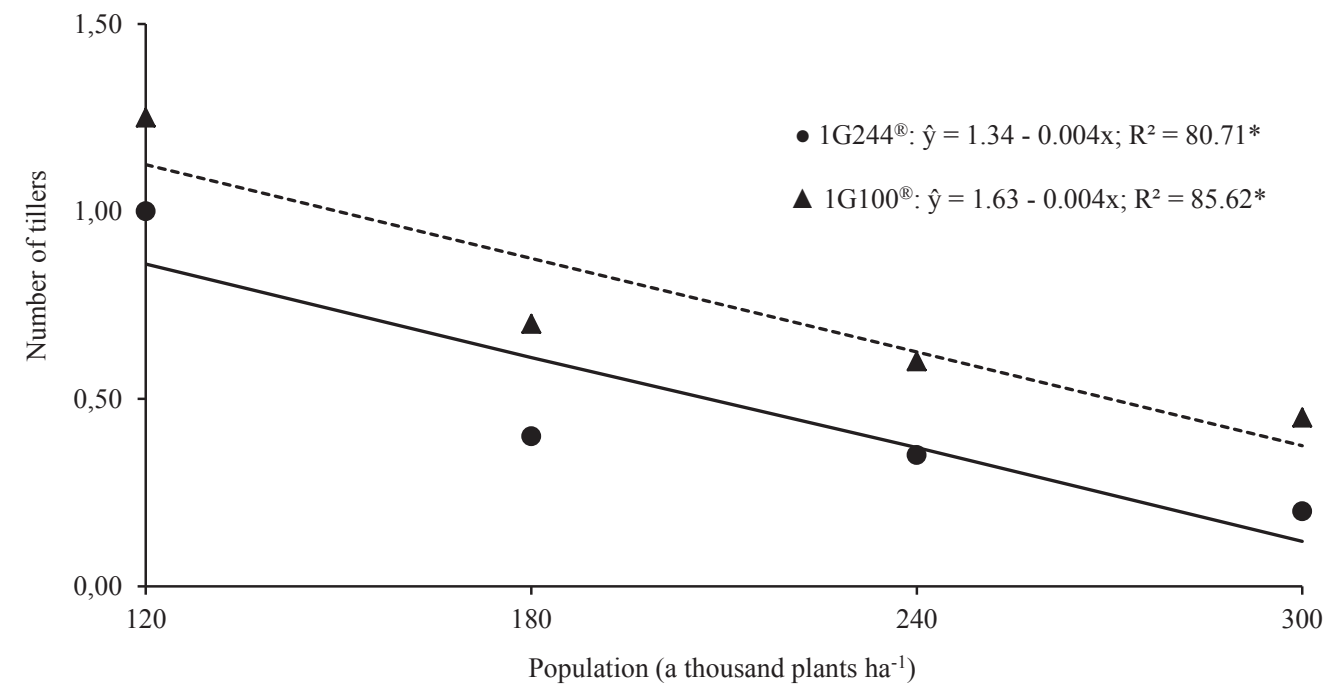

Figure 2. Plant height (a), stem diameter (b), and number of tillers (c) in sorghum grown in different plant arrangements. Rio Verde (GO), 2017.

The stem diameter was influenced by the plant population and sowing spacing only for the $1 \mathrm{G} 100^{\circledR}$ hybrid. There was an effect of reducing the spacing between the lines, with an increase of $11 \%$ in the measurement of this response variable when the hybrid $1 \mathrm{G} 100^{\circledR}$ was grown in the population of 300 thousand plants ha-1 (Table 2). Still, population density had a significant influence, showing an inverse relationship with plant height and reducing stem diameter in a linear fashion by $25 \%$ and $20 \%$ as plant density increased, between the smallest and the largest population for hybrids $1 \mathrm{G} 244^{\circledR}$ and $1 \mathrm{G} 100^{\circledR}$, respectively (Figure 2b).

Table 2

Average values of grain sorghum characteristics cultivated in different plant arrangements. Rio Verde (GO), 2017

\begin{tabular}{|c|c|c|c|c|c|c|c|c|c|c|}
\hline \multirow{4}{*}{$\begin{array}{l}\text { Spacing } \\
\text { (m) }\end{array}$} & \multicolumn{5}{|c|}{$1 \mathrm{G} 244^{\circledR}$} & \multicolumn{5}{|c|}{$1 \mathrm{G} 100^{\circledR}$} \\
\hline & \multicolumn{10}{|c|}{ Population (a thousand plants ha-1) } \\
\hline & 120 & 180 & 240 & 300 & Average & 120 & 180 & 240 & 300 & Average \\
\hline & \multicolumn{10}{|c|}{ Plant height $(\mathrm{m})$} \\
\hline 0.25 & 1.15 & 1.17 & 1.19 & 1.21 & $1.18 \mathrm{~b}$ & 1.19 & 1.22 & 1.24 & 1.27 & $1.23 \mathrm{~b}$ \\
\hline 0.50 & 1.16 & 1.21 & 1.23 & 1.24 & $1.21 \mathrm{a}$ & 1.21 & 1.26 & 1.28 & 1.29 & $1.26 \mathrm{a}$ \\
\hline \multirow[t]{2}{*}{ Average } & 1.16 & 1.19 & 1.21 & 1.23 & & 1.20 & 1.24 & 1.26 & 1.28 & \\
\hline & \multicolumn{10}{|c|}{ Stem diameter $(\mathrm{cm})$} \\
\hline 0.25 & 1.90 & 1.77 & 1.56 & 1.42 & $1.66 \mathrm{a}$ & $1.78 \mathrm{~A}$ & $1.60 \mathrm{~A}$ & $1.59 \mathrm{~A}$ & $1.55 \mathrm{~A}$ & $1.57 \mathrm{~b}$ \\
\hline 0.50 & 1.85 & 1.65 & 1.60 & 1.40 & $1.62 \mathrm{a}$ & $1.87 \mathrm{~A}$ & $1.51 \mathrm{~A}$ & $1.41 \mathrm{~A}$ & $1.38 \mathrm{~B}$ & $1.63 \mathrm{a}$ \\
\hline \multirow[t]{2}{*}{ Average } & 1.87 & 1.71 & 1.58 & 1.41 & & 1.83 & 1.56 & 1.54 & 1.47 & \\
\hline & \multicolumn{10}{|c|}{ Tillering } \\
\hline 0.25 & 1.0 & 0.40 & 0.30 & 0.20 & $0.48 \mathrm{a}$ & 1.5 & 1.0 & 0.80 & 0.60 & $0.98 \mathrm{a}$ \\
\hline 0.50 & 1.0 & 0.40 & 0.40 & 0.20 & $0.50 \mathrm{a}$ & 1.0 & 0.4 & 0.4 & 0.30 & $0.53 \mathrm{~b}$ \\
\hline Average & 1.00 & 0.40 & 0.35 & 0.20 & & 1.20 & 0.70 & 0.60 & 0.45 & \\
\hline
\end{tabular}


continuation

\begin{tabular}{|c|c|c|c|c|c|c|c|c|c|c|}
\hline \multirow[b]{2}{*}{0.25} & \multicolumn{10}{|c|}{ Panicle length $(\mathrm{cm})$} \\
\hline & 29.6 & 28.9 & 28.1 & 26.8 & $28.4 \mathrm{a}$ & 30.2 & 28.6 & 28.5 & 26.9 & $28.6 \mathrm{a}$ \\
\hline 0.50 & 29.9 & 28.3 & 27.6 & 26.4 & $28.1 \mathrm{a}$ & 29.5 & 28.2 & 27.9 & 27.8 & $28.4 \mathrm{a}$ \\
\hline \multirow[t]{2}{*}{ Average } & 29.8 & 28.6 & 27.8 & 26.6 & & 29.9 & 28.9 & 28.1 & 27.3 & \\
\hline & \multicolumn{10}{|c|}{ Panicle mass $(\mathrm{g})$} \\
\hline 0.25 & 77.5 & 64.2 & 56.3 & 48.0 & $61.5 \mathrm{a}$ & 71.3 & 56.2 & 52.8 & 45.8 & $56.5 \mathrm{a}$ \\
\hline 0.50 & 77.7 & 60.5 & 55.7 & 51.7 & $61.4 \mathrm{a}$ & 62.2 & 54.3 & 51.2 & 47.2 & $53.7 \mathrm{a}$ \\
\hline \multirow[t]{2}{*}{ Average } & 77.6 & 62.3 & 56.0 & 49.9 & & 66.8 & 55.2 & 51.9 & 46.5 & \\
\hline & \multicolumn{10}{|c|}{ Mass of a thousand grains (g) } \\
\hline 0.25 & 20.9 & 19.3 & 19.1 & 18.3 & $19.4 \mathrm{a}$ & 23.5 & 22.4 & 22.1 & 21.8 & $22.5 \mathrm{~b}$ \\
\hline 0.50 & 20.6 & 19.5 & 19.4 & 19.3 & $19.6 \mathrm{a}$ & 24.5 & 24.0 & 23.8 & 23.6 & $23.9 \mathrm{a}$ \\
\hline \multirow[t]{2}{*}{ Average } & 20.8 & 19.4 & 19.3 & 18.8 & & 24.0 & 23.2 & 22.9 & 22.7 & \\
\hline & \multicolumn{10}{|c|}{ Yield $\left(\mathrm{kg} \mathrm{ha}^{-1}\right)$} \\
\hline 0.25 & 5245 & 6073 & 6941 & 7255 & $6378 \mathrm{a}$ & 5162 & 6184 & 7388 & 7808 & $6636 a$ \\
\hline 0.50 & 5438 & 6241 & 6784 & 7127 & $6398 \mathrm{a}$ & 5429 & 6577 & 7307 & 7675 & $6747 a$ \\
\hline Average & 5341 & 6157 & 6863 & 7191 & & 5296 & 6381 & 7348 & 7741 & \\
\hline
\end{tabular}

Averages followed by the same between spacings, for each hybrid, do not differ significantly by the $\mathrm{F}$ test $(\mathrm{p} \leq 0.05)$.

According to Taiz and Zeiger (2013), plants compete for sunlight so that the leaves form a canopy, which absorbs light, influencing the photosynthetic rate and plant growth. Both stem diameter and plant height were influenced by light intensity, since narrower spacing $(0.25 \mathrm{~m})$ provided a larger stem diameter due to less competition for light between plants. However, high plant density promotes greater intraspecific competition, interfering in the quality of the light reaching the shallow leaves, increasing the amount of extreme red (VE) and decreasing the amount of red (V) (Rajcan \& Swanton, 2001), which increases the VE/V ratio, changing several morphological characteristics, stimulating apical dominance and elongation of internodes and, consequently, reducing the stem diameter (Ballaré $\&$ Cassal, 2000) and number of tillers. Despite the morphological changes in the sorghum submitted to dense sowing, lodging of the plants was not observed in any of the experiments.

The number of tillers differed between the spacing distances evaluated for the hybrid $1 \mathrm{G} 100^{\circledR}$. Plants sown $0.25 \mathrm{~m}$ apart had more tillers than those sown
$0.50 \mathrm{~m}$ apart. The addition of plants in the cultivation area reduced the number of tillers by $80 \%$ and $63 \%$ for hybrids $1 \mathrm{G} 244^{\circledR}$ and $1 \mathrm{G} 100^{\circledR}$, respectively (Figure 2c). Tillering is influenced by the incident light reaching the neck of the plant. In smaller populations, this part receives greater luminosity, resulting in hormonal alteration, which stimulates the emission of tillers by the main plant due to its greater availability of photoassimilate reserves (Magalhães \& Durães, 2003). In studies evaluating tillering in sorghum cultivars under different plant arrangements, it was observed that closer spacing associated with larger plant populations provided fewer sorghum tillers (Jones \& Johnson, 1997; Baumhardt \& Howell, 2006).

The yield components were not influenced by the distance between sowing lines, except for the mass of a thousand grains for the hybrid $1 G 100^{\circledR}$, which was higher with $0.50 \mathrm{~m}$ spacing. The addition of plants per hectare significantly affected the yield components. All characteristics showed a decreasing linear behavior (Figures 3a, 3b, and $3 c)$. For the characteristics panicle length, panicle 
mass, and mass of a thousand grains, there were average reductions of $11 \%$ and $9 \%, 36 \%$ and $30 \%$,

respectively, between the populations of 120 and $10 \%$ and $5 \%$ for hybrids $1 \mathrm{G} 244^{\circledR}$ and $1 \mathrm{G} 100^{\circledR}$,
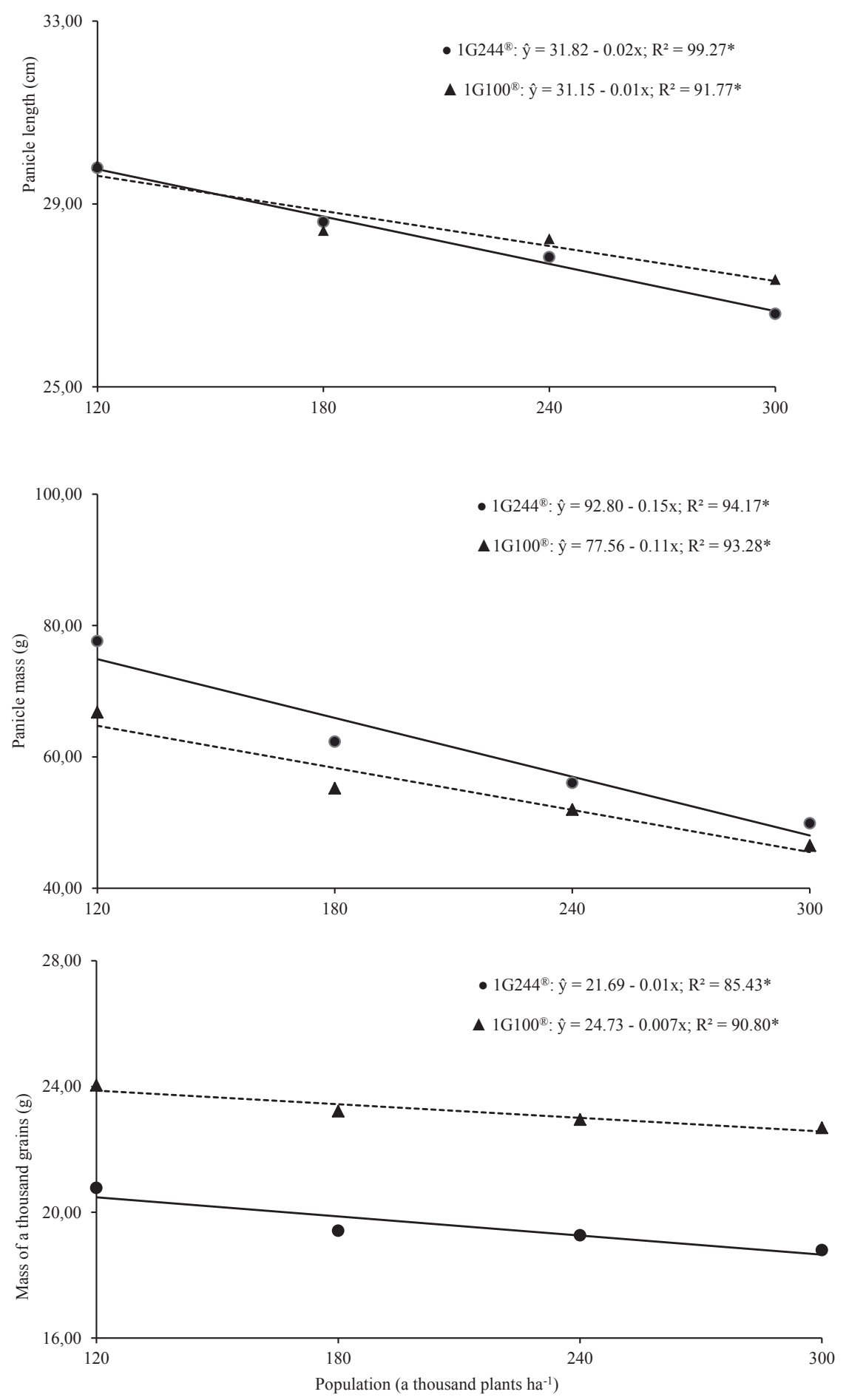

Figure 3. Panicle length (a), panicle mass (b), and thousand grain mass (c) in sorghum grown in different plant arrangements. Rio Verde (GO), 2017. 
The yield components are influenced by the population density, which in turn affects the leaf area index; at higher densities, less light penetrates the canopy, reducing photosynthesis (Gan, Stulen, Van Keulen, \& Kuiper, 2002), which decreases the production and partitioning of photoassimilates for the reproductive drains of the plants. These correlations are emphasized in the work of Bayu, Rethman, Hammes and Alemu (2006), who observed that sorghum grown at high population densities presented a reduction in yield components. Graniferous sorghum exhibits grain yield compensation when subjected to smaller plant populations due to the number of grains per panicle and the higher incident radiation per plant (Montagner, Lovato, \& Garcia, 2004). Thus, high populations do not present advantages in individual yield per plant.

In turn, yield was influenced only by the increase in the plant population in both hybrids. Considering the two cultivated hybrids, for each thousand plants added per hectare, there was an average increase of $12.1 \mathrm{~kg}$ (Figure 4). The average yield between the smallest and largest population was $1850 \mathrm{~kg} \mathrm{ha}^{-1}$ and $2445 \mathrm{~kg} \mathrm{ha}^{-1}$ for hybrids $1 \mathrm{G} 244^{\circledR}$ and $1 \mathrm{G} 100^{\circledR}$, respectively.

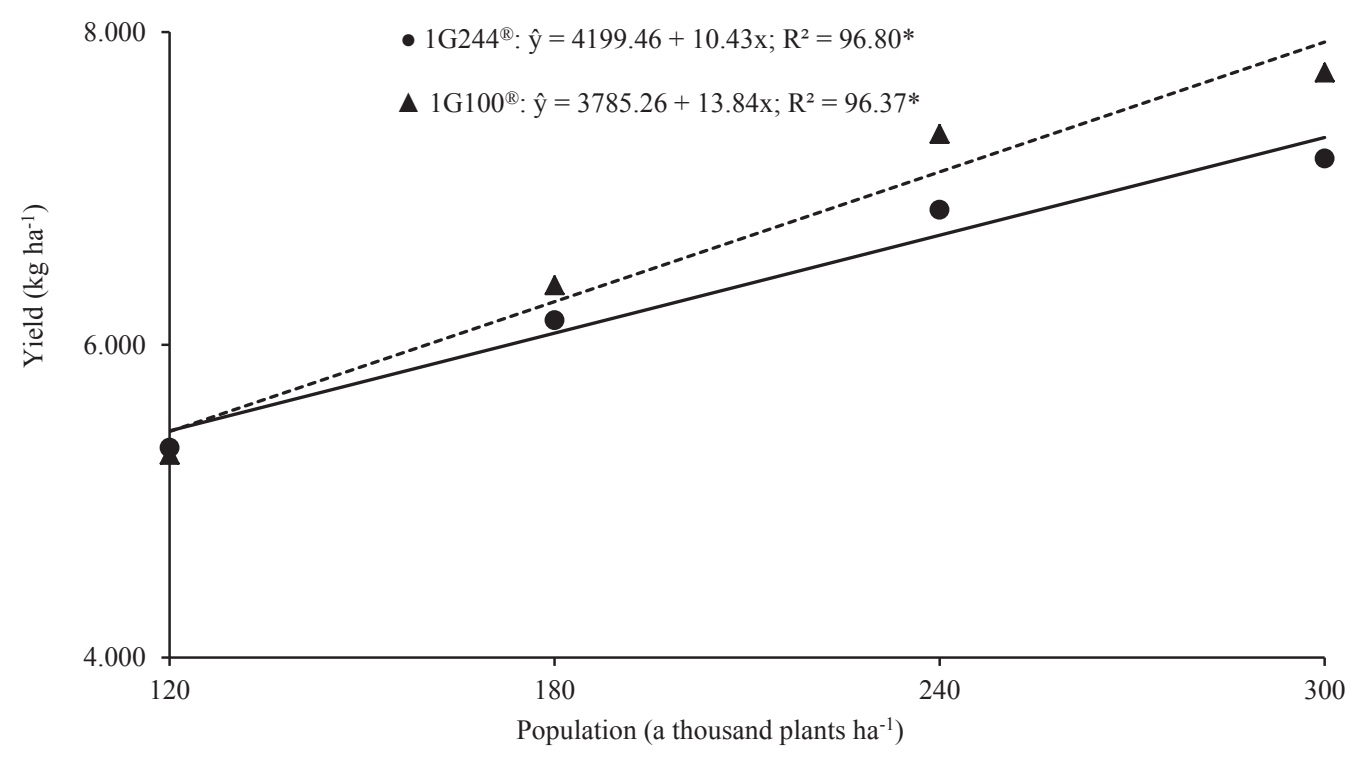

Figure 4. Grain yield of sorghum grown in different plant arrangements. Rio Verde (GO), 2017.

High yield can be obtained through wide variation in the plant population, given the response that sorghum hybrids can express. Therefore, when grown at high population densities, there is a reduction in yield components, minimizing yield per plant. However, sorghum plants have a high capacity for space compensation. Therefore, at low population densities, production per plant is maximized with low yield per area and, with increasing density, individual yield per plant is reduced, but yield per area increases (Fornasieri \& Foranasieri, 2009).
This is confirmed by the results described in the literature in which studies carried out by Freitas, Borger and Ticelli (2014) in Brazil showed that the population density interfered in the yield components; however, the grain yield was not affected for most of the evaluated hybrids.

\section{Conclusion}

The reduction in the inter-row sowing spacing from $0.50 \mathrm{~m}$ to $0.25 \mathrm{~m}$ partially interferes in the 
agronomic characteristics of sorghum, except for panicle length, panicle mass, and grain yield.

The increase in the plant population in the cultivation area promotes plants of a larger size, with a smaller stem diameter and a lower number of tillers.

Although larger plant populations promote a reduction in yield components, which compromises individual yield per plant, the increase in sowing density provides increases in grain yield per area.

\section{Acknowledgments}

To COMIGO Technological Center and the University of Rio Verde, for providing all the necessary infrastructure for carrying out the experiments.

\section{References}

Al-Bedairy, N. R., Alsaadawi, I. S., \& Shati, R. K. (2013). Combining effect of allelopathic Sorghum bicolor L. (Moench) cultivars with planting densities on companion weeds. Archives of Agronomy and Soil Science, 59(7), 955-961. doi: 10.1080/03650340.2012.697995

Albuquerque, C. J. B., Von Pinho, R. G., Brant, R. S., \& Mendes, M. C. (2011). Espaçamento e densidade de semeadura para cultivares de sorgo granífero no semiárido. Bragantia, 70(2), 278-285. doi: 10.1590/ S0006-87052011000200005

Avelino, P. M., Neiva, J. N. M., Araújo, V. L., Alexandrino, E., Santos, A. C., \& Restle, J. (2011). Características agronômicas e estruturais de híbridos de sorgo em função de diferentes densidades de plantio. Revista Ciência Agronômica, 42(2), 534-541. doi: 10.1590/ S1806-66902011000200037

Ballaré, C. L., \& Casal, J. J. (2000). Light signals perceived by crop and weed plants. Field Crops Research, 67(1), 149-160. doi: 10.1016/S03784290(00)00090-3

Baumhardt, R. L., \& Howell, T. A. (2006). Seeding practices, cultivar maturity, and irrigation effects on simulated grain sorghum yield. Agronomy Journal, 98(3), 462-470. doi: 10.2134/agronj2005.0156
Bayu, W., Rethman, N. F. G., Hammes, P. S., \& Alemu, G. (2006). Effects of farmyard manure and inorganic fertilizers on sorghum growth, yield and nitrogen use in a Semi-arid area of Ethiopia. Plant Nutrition Journal, 29(2), 391-407. doi: 10.1080/01904160500320962

Cox, W. J., Cherney, J. H., \& Shields, E. (2010). Soybeans compensate at low seeding rate but not at high thinning rates. Agronomy Journal, 102(4), 1238-1243. doi: 10.2134/agronj2010.0047

Dow Agrosciences (2018). Hibridos de sorgo. Recuperado de http://www.dowagro.com/pt-br/ brasil/product-finder/sementes/hibridos-de-sorgo

Empresa Brasileira de Pesquisa Agropecuária (2013). Sistema brasileiro de classificação de solos (3a ed.). Brasília: EMBRAPA Solos.

Ferreira, D.F.(2011). Sisvar: a computer statistical analysis system. Ciência e Agrotecnologia, 35(6), 1039-1042. doi: 10.1590/S1413-70542011000600001

Fornasieri, D., F' ., \& Fornasieri, J. L. (2009). Manual da cultura do sorgo. Jaboticabal, SP: FUNEP.

Freitas, R. S., Borger, W. L. B., \& Ticelli, M. (2014). Sorgo granífero - desempenho agronômico de cultivares. Pesquisa \& Tecnologia, 11(1), 1-6.

Gan, Y., Stulen, I., Van Keulen, H., \& Kuiper, P. J. C. (2002). Physiological response of soybean genotypes to plant density. Field Crops Research, 74(2/3), 231241. doi: 10.1016/S0378-4290(01)00212-X

Hammer, G. L., \& Broad, I. J. (2003). Genotype and environment effects on dynamics of harvest index during grain filling in sorghum. Agronomy Journal, 95(1), 199-206. doi: 10.2134/agronj2003.1990

Jones, O. R., \& Johnson, G. L. (1997). Evaluation of a short season, high-density production strategy for dryland sorghum. Texas: USDA-ARS.

Magalhães, P. C., \& Durães, F. O. M. (2003). Ecofisiologia da produção de sorgo. Sete Lagoas: EMBRAPA Milho e Sorgo. Comunicado Técnico 87.

May, A., Campanha, M. M., Silva, A. F., Freitas, R. S., \& Albuquerque, C. J. B. (2014). Arranjo de plantas no plantio. In A. Borém, L. Pimentel, \& R. Parrela (Eds.), Sorgo do plantio a colheita (pp. 119-143). Viçosa, MG: UFV.

Montagner, D., Lovato, C., \& Garcia, D. C. (2004). Perdas aleatórias na população inicial e sua relação com o rendimento de grãos em sorgo. Revista Brasileira de Agrociência, 10(3), 281-285. doi: 10.18539/CAST. V10I3.958 
Rajcan, I., \& Swanton, C. J. (2001). Understanding maize-weed competition: resource competition, light quality and the whole plant. Field Crops Research, 71(1), 139-150. doi: 10.1016/S0378-4290(01)001599

Snider, J. L., Rapera, R. L., \& Schwabb, E. B. (2012). The effect of row spacing and seeding rateon biomass production and plant stand characteristics of nonirrigated photoperiod-sensitive sorghum (Sorghum bicolor (L.) Moench). Industrial Crops and Products, 37(1), 527-535. doi: 10.1016/j.indcrop.2011.07.032
Stichler, C., McFarland, M., \& Coffman, C. (1997). Irrigated and dryland grain sorghum production south and southwest Texas. Bulletin of Texas Agricultural Extension Service, College Station, 6048, 1-13. Retrieved from: https://agrilifeextension.tamu.edu/ library/farming/irrigated-and-dryland-sorghumproduction-in-south-and-southwest-texas/

Taiz, L., \& Zeiger, E. (2013). Fisiologia vegetal (5a ed.). Porto Alegre: Artmed.

Walker, E. R., Mengistu, A., Bellaloui, N., Koger, C. H., Roberts, R. K., \& Larson, J. A. (2010). Plant population and row-spacing effects on maturity group III soybean. Agronomy Journal, 102(3), 821826. doi: 10.2134/agronj2009.0219 